\title{
An economic assessment of the contribution of biological control to the management of invasive alien plants and to the protection of ecosystem services in South Africa
}

\author{
Willem J. de Lange $\cdot$ Brian W. van Wilgen
}

Received: 23 October 2009/Accepted: 26 January 2010/Published online: 1 July 2010

(C) Springer Science+Business Media B.V. 2010

\begin{abstract}
This study is a first attempt at a holistic economic evaluation of South African endeavours to manage invasive alien plants using biological control. Our focus was on the delivery of ecosystem services from habitats that are invaded by groups of weeds, rather than by each individual weed species. We established the net present value of the weed biological control efforts, and derived benefit:cost ratios by comparing this value (a cost) to the estimated value of ecosystem services protected by weed biological control. We identified four major functional groupings of invading alien plants, and assessed their impact on water resources, grazing and biodiversity. We estimated the area that remained free of invasions due to all historic control efforts in South Africa, and the proportion that remained free of invasion as a result of biological control (which was initiated in 1913). The estimated value of potential ecosystem services amounted to 152 billion South African rands (ZARpresently, about US\$19.7 billion) annually. Although an estimated ZAR 6.5 billion was lost every year due to invading alien plants, this would have amounted to an estimated additional ZAR 41.7 billion had no control been carried out, and 5-75\% of this protection was due to biological control. The benefit:cost ratios ranged
\end{abstract}

W. J. de Lange $\cdot$ B. W. van Wilgen $(\bowtie)$

Centre for Invasion Biology, CSIR Natural Resources and the Environment, PO Box 320, Stellenbosch 7599, South Africa

e-mail: bvwilgen@csir.co.za from 50:1 for invasive sub-tropical shrubs to 3,726:1 for invasive Australian trees. Benefit:cost ratios remained positive and our conclusion, that biological control has brought about a considerable level of protection of ecosystem services, remains robust even when our estimates of the economic impacts of key variables (i.e. sensitivity analyses of indeterminate variables) were substantially reduced.

Keywords Benefit-cost analysis . Invasive alien plants - Water resources . Grazing · Biodiversity

\section{Introduction}

Invasive alien plants are a large and growing problem worldwide, as they threaten the integrity of ecosystems and the services that they deliver to humanity. The growth in human populations has been accompanied by unprecedented encroachment on terrestrial ecosystems, and the expansion of global trade has led to the widespread distribution of large numbers of species beyond their native ranges. Both have led to an increase in the number and distribution of invasive alien plant species, causing significant economic losses (Perrings et al. 2010; Pimentel 2002).

Land managers have responded to the threat of invasive alien plants in a variety of ways. Several countries have developed national strategies for 
dealing with the problem (see, for example, Federal Interagency Committee 1998), and a global strategy has been proposed (McNeeley et al. 2001). All of these approaches support the concept of integrated control, which includes the appropriate use of combinations of mechanical, chemical and biological control, and habitat management.

The biological control of invasive alien plants, using plant-feeding insects and pathogens (also called "weed biological control") provides a long-tem, self-sustaining solution to many invasive alien plant problems (Moran et al. 2005). Numerous studies (Buhlea et al. 2005; Culliney 2005; De Wit et al. 2001; Jarvis et al. 2006; Law 2007; McConnachie et al. 2003; Pimentel et al. 2005; Pringle and Heunis 2006; van Wilgen et al. 2000, 2001, 2004; van Wyk and van Wilgen 2002) have discussed or assessed the economic returns on investments in biological control, but none could be regarded as comprehensive as almost all dealt with single weed species. One of the few more comprehensive reviews of weed biological control was done in Australia (Page and Lacey 2006) and concluded that national weed biological control realised significant long term returns on investments, with benefits far outweighing the total costs. However, this finding was based on a range of individual assessments, which would have led to double-counting of benefits. We are not aware of any study that has attempted to quantify the benefits of biological control in terms of ecosystem services at a landscape (or biome) scale, where numerous species invade the landscape. Such studies are complicated, as the magnitude of impacts is poorly understood, and the conduct of such studies requires numerous assumptions.

South Africa has made significant investments in weed biological control over the past century (Zimmermann et al. 2004). In this paper, we have developed an approach to assess the costs and benefits of South Africa's weed biological research effort. Our focus was on the delivery of ecosystem services from habitats that are invaded by groups of weeds, rather than on single weed species.

\section{Methods}

\section{Selection of species}

Our study focussed on four groups of invasive alien plant species (Table 1) that invade particular ecosystems, where they create a suite of similar problems. Groups were based on the premise that if one such species were to be removed from the ecosystem concerned (for example by means of effective integrated control), one of the others may simply replace it, with no benefit being gained from the control effort. By using a group approach, questions about the relative contribution of biological control to the alleviation of problems can be addressed more holistically.

Table 1 Groups of invasive alien plant species in South Africa, and ecosystems impacted upon by each group

\begin{tabular}{llll}
\hline Invasive alien plant species group & $\begin{array}{l}\text { Genera of invasive } \\
\text { plants }\end{array}$ & $\begin{array}{l}\text { Principal ecosystems } \\
\text { impacted }\end{array}$ & Other ecosystems impacted \\
\hline Fire-adapted trees & $\begin{array}{l}\text { Pinus } \\
\text { Hakea }\end{array}$ & Fynbos shrublands & Savanna and grasslands \\
Perennial invasive Australian trees & $\begin{array}{l}\text { Acacia } \\
\text { Leptospermum }\end{array}$ & $\begin{array}{l}\text { Fynbos shrublands } \\
\text { Grassland }\end{array}$ & Riparian zones in all biomes \\
& Paraserianthes & Savanna & None \\
Invasive succulents (cacti) & Opuntia & Karoo arid \\
& Cereus & shrublands & Grassland \\
Harrisia & Savanna & Savanna \\
& Lantana & Grassland & \\
\hline
\end{tabular}


Costs of biological control research

Biological control research was initiated in South Africa in 1913, but was most actively pursued from the 1970s onwards. In total, 77 biological control agents had been investigated for use against 11 genera of invasive alien plants, ranging from 1 agent against Pinus, to 21 agents against Lantana. Of these, 68 have been released between 1913 (on Opuntia) and 2006 (on Hakea, see Zimmermann et al. 2004 for a full list). We interviewed researchers in all of the major institutes that had conducted research into biological control to establish the time period, number of researchers, and project running costs and salaries associated with each biological control agent (whether or not that agent species was eventually released). The research was mainly conducted at the South African Agricultural Research Council's Plant Protection Research Institute, but also included work at two universities (Cape Town and Rhodes). From this information, we were able to reconstruct the approximate annual research costs related to exploration, to research on safety-screening and other pre-release preliminaries in the laboratory, and as appropriate, to the costs of actual releases, redistribution, monitoring and impact-evaluation of the individual biological control agents in the field. These costs were then inflated to 2008 values, using annual inflation rates. The costs did not include those associated with a unique implementation programme, introduced in 2002, in which certain biological control agents were mass-reared at four facilities, and released in the field (Zimmermann et al. 2004), as these were not regarded as research investments.

\section{Value of ecosystem services}

Data on the magnitude of ecosystems services, and the current estimated reductions in the magnitude of these services due to invasive alien plants (van Wilgen et al. 2008) were used as a basis for estimating the value of biological control. These data were provided for five major terrestrial biomes in South Africa: fynbos (mediterranean shrublands); grassland; savanna and thicket; Nama karoo (arid shrublands); and succulent karoo. For each biome, we used the estimates of annual flows of benefits for three major ecosystem services as a basis for estimating monetary values. The services were the provision of water (quantified as mean annual runoff); the provision of grazing for livestock (quantified as livestock stocking rates); and biodiversity (a biodiversity intactness index).

We used an estimate of the unit price of water in both in its serviced ( $64 \%$ of total use) and un-serviced (34\% of total use) forms, which is sold at 0.143 and 5.395 South African rands (ZAR) per $\mathrm{m}^{3}$, respectively (De Lange and Kleynhans 2008). The volumebased weighted average of ZAR 1.89 per $\mathrm{m}^{3}$ was used to estimate the value of water provision by ecosystems.

We used a weighted average price for livestock in South Africa as a basis for quantifying the impact of invasions on livestock numbers in monetary terms. This amounted to ZAR 2471 per large stock unit (Statistics South Africa 2004).

Van Wilgen et al. (2008) used the Biodiversity Intactness Index (BII) developed by Scholes and Biggs (2005). This index translates expert estimates of land use impacts on vertebrate populations into a spatial estimate of biodiversity integrity. It is an aggregate index that combines information on ecosystem distribution, species richness and the extent and impact of major land uses on biodiversity. It is intended to provide an easy-to-understand overview of the state of biodiversity for policy makers and the public. In essence, BII is a richness and areaweighted average of the impact of a set of land use activities on populations of plants, mammals, birds, reptiles and frogs in a given area. If the population impact $\left(I_{i j k}\right)$ is defined as the relative population of taxon $i$ (as compared to the reference state) under land use activity $k$ in ecosystem $j$, then BII gives the average remaining fraction of the populations of all species considered:

$$
\mathrm{BII}=\frac{\sum_{i} \sum_{j} \sum_{k} R_{i j} A_{j k} I_{i j k}}{\sum_{i} \sum_{j} \sum_{k} R_{i j} A_{j k}}
$$

where $R_{i j}=$ Richness (number of species) of taxon $i$ in ecosystem $j ; A_{j k}=$ Area of land use $k$ in ecosystem $j$.

Data on the population impact $\left(I_{i j k}\right)$ are currently not available, so Scholes and Biggs (2005) consulted three or more taxonomic specialists for each taxon to produce expert estimates of impact per land use per taxon per biome. These estimates were generated for protected areas, light use, cultivation, plantations, and urban and degraded areas. The index has been applied to South Africa by Biggs et al. (2006) based on the 1996 
national land cover data which recognises areas of cultivation, plantations, urban development, protected areas, degraded areas and natural areas (equivalent to areas of light use). This data layer represents biodiversity intactness without invasive alien plants.

The unit pricing of biodiversity was based on numerous studies that have attempted to place a monetary value on the ecosystem services derived from biodiversity, including the harvesting of natural products as well as non-use values (Hassan 2003; Higgins et al. 1997; Shackleton and Shackleton 2004; Turpie et al. 2003; Turpie 2003); see Turpie (2004) for a review. We assumed a proportional relationship between biodiversity intactness and the magnitude of ecosystem services. We deducted the value of water and grazing (as these were already accounted for) and then reduced the value of the remaining combined services in each of the major terrestrial biomes separately, using van Wilgen et al. (2008)'s estimates of the impact of alien plant invasions on the biodiversity intactness in the biome concerned. This yielded values of ZAR 1,021, 386, 110, 33 and 33 per ha for fynbos shrublands, savanna and thicket, grassland, succulent karoo and Nama karoo, respectively.

Impacts of invasive alien plant groups

on ecosystem services

As the invasive alien plants groups occurred in more than one biome, we used spatial cover data from Le Maitre et al. (2000) to determine the proportion of the cover of each group that was found in each biome. The loss of ecosystem services due to invasion by each group was expressed in monetary terms using the above unit prices, and the relative cover of the group in the biome concerned. The estimated reduction in the value of ecosystem services was in direct proportion to the relative cover of each of the invasive alien plant groups in each biome. The invasive succulent and subtropical shrub groups do not have any noticeable impact on water resources (van Wilgen et al. 2008), so the impact of these groups on water resources was taken to be zero.

Contribution of biological control to reducing impacts on ecosystem services

Three estimates of the value of ecosystem services were available at the start of this study (Fig. 1). These were

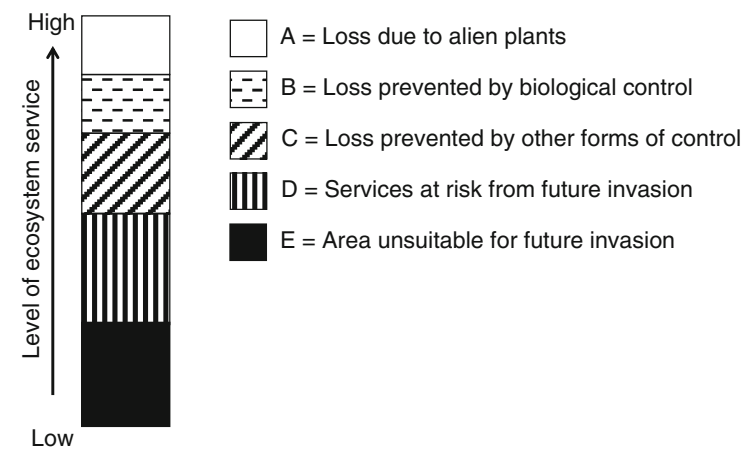

Fig. 1 Apportioning of ecosystem services according to the impact of invading alien plants and their control. Estimates of services from an ecosystem unaffected by alien plants $(\mathrm{A}+\mathrm{B}+\mathrm{C}+\mathrm{D}+\mathrm{E})$, and for services from an ecosystem with current levels of invasion $(\mathrm{B}+\mathrm{C}+\mathrm{D}+\mathrm{E}$, which results from both invasion rates and control efforts) were available, and A was obtained by subtraction. The proportion unsuitable for future invasion (E) was also available from estimates based on climatic envelope modelling (Rouget et al. 2004). Estimates for the proportion that would have been affected by alien plants had no control taken place $(\mathrm{A}+\mathrm{B}$ $+\mathrm{C}$ ), and the proportion of prevention of loss of services attributable to biological control and other forms of control (the ratio $\mathrm{B}: \mathrm{C}$ ) were key variables that required quantification (see text)

(1) the value that could be expected from ecosystems that were unaffected by alien plants; (2) the current values, which reflect the extent of invasion as well as the contribution of past control efforts; and (3) the future value when invasive alien plants occupy all of the available suitable habitat (van Wilgen et al. 2008). To estimate the contribution of biological control to the overall control of alien plants, and therefore to the protection of ecosystem services, estimates for two additional key variables were still required.

The first key variable was the relative proportion of the prevention of loss of services attributable to biological control relative to other forms of control (the ratio B:C in Fig. 1). As there were no data on these ratios, we used expert opinion to estimate this proportion. We conducted one-on-one, two-hour discussions with recognised experts for each of the alien plant groups. Following that, we held broader discussions with larger workshops, typically with five or more experts who had in excess of 100 years of combined experience in biological control research and practice in South Africa.

The second key variable was the proportion of land that would have remained un-invaded had 
invasive alien plants not been subjected to any form of control ( $\mathrm{A}+\mathrm{B}+\mathrm{C}$ in Fig. 1). To derive an approximation of this proportion, we relied on historical records (Richardson et al. 1997) that suggest that invasive plant spread began in 1700 in the fynbos, and in 1850 in the karoo, grassland and savanna biomes (fynbos has a much longer history of alien plant introductions), and that the weeds would achieve their maximum densities and land 'occupation' by about the year 2150. The time from the start of the spread of the invasive plants to the present (2009) was expressed as a percentage of the time between the start of spread and 2150, assuming that the alien plant species expanded at a linear rate until they occupied all suitable habitats in given area. The total possible level of ecosystem services at risk from invasion $(\mathrm{A}+\mathrm{B}+\mathrm{C}+\mathrm{D})$ was multiplied by this percentage to estimate the value of $\mathrm{A}+\mathrm{B}+\mathrm{C}$ (Fig. 1).

Benefit:cost estimation and sensitivity analyses

We estimated a benefit:cost ratio (the value of ecosystem services protected compared to the cost of biological control research) for each group of weeds. Net present values for ecosystem services were estimates from future annual benefit flows, discounted at $8 \%$ over 140 years. As the potential errors in the estimates of both of the abovementioned key variables could be large, we performed sensitivity analyses with respect to the effect of these estimates on our findings. We first reduced our estimate of the value of ecosystem services protected by all forms of historic control to lower values (between 85 and $25 \%$ of the estimated base value). For each of these reduced values, we then calculated the ratio of the proportion of the control attributable to biological control as compared to other forms of control that would have delivered a benefit:cost ratio of $1: 1$.

\section{Results}

Costs of biological control research

The total cost of biological control research on the four invasive alien plant groups amounted to ZAR 102 million, expressed in 2008 values (Table 2). The
Table 2 Net present (2008) value of the cost of biological control research for five groups of invasive alien plants (see Table 1 for alien plant groups; ZAR = South African rands; $1 \mathrm{US} \$=7.7$ rands in January 2010)

\begin{tabular}{lr}
\hline Invasive alien plant species group & $\begin{array}{l}\text { Estimated } \\
\text { costs (ZAR) }\end{array}$ \\
\hline Fire-adapted trees & $10,320,124$ \\
Perennial invasive Australian trees & $27,941,017$ \\
Invasive succulents (cacti) & $13,626,030$ \\
Subtropical shrubs & $50,563,394$ \\
Total & $102,450,565$ \\
\hline
\end{tabular}

cost for individual groups covered an approximate fivefold range, from ZAR 10 million for fire-adapted trees to ZAR 50 million for subtropical shrubs.

Value of ecosystem services

The estimated potential annual value of ecosystem services from extant un-transformed ecosystems amounted to ZAR152 billion (Table 3). Most of this value $(63 \%)$ was derived from water, while grazing and biodiversity contributed 22 and $15 \%$, respectively. Of the total value, ZAR6.5 billion was estimated as having been lost due to current levels of alien plant infestation, and ZAR41.7 billion was estimated to have been saved by the complete range of control efforts.

Contribution of alien plant groups to impacts in biomes

The relative impacts of the various groups of invasive alien plants varied between the different biomes (Table 4). Fire-adapted trees (pines and hakeas) contributed $20 \%$ of the relative impact in fynbos ecosystems, and relatively little elsewhere. Invasive Australian trees dominated in all ecosystems except savanna and thicket, contributing between 78 and $96 \%$ of the impact. Savanna ecosystems suffered impacts from all groups of plants.

Biological control was estimated to have resulted in substantial levels of protection for these ecosystem services (Table 5). The annual value of services from ecosystems that would have been invaded by invasive Australian trees amounted to ZAR 8.3 billion, with savings of ZAR 2.6 billion and ZAR 1.1 billion arising from the protection of water and grazing resources in 
Table 3 The estimated annual value of ecosystem services (million ZAR; ZAR = South African rands; 1 US $\$=7.7$ rands in January 2010) derived from five terrestrial ecosystems in South Africa under a scenario of no invasion, at current

\begin{tabular}{|c|c|c|c|c|}
\hline Ecosystem service & Biome & $\begin{array}{l}\text { Pristine un-invaded } \\
\text { ecosystems }\end{array}$ & $\begin{array}{l}\text { Current levels } \\
\text { of infestation }\end{array}$ & $\begin{array}{l}\text { Protected by historic } \\
\text { control efforts }\end{array}$ \\
\hline \multirow[t]{6}{*}{ Water } & Fynbos & 12,832 & 10,814 & 1,230 \\
\hline & Grassland & 50,486 & 48,896 & 11,909 \\
\hline & Succulent Karoo & 694 & 508 & 42 \\
\hline & Nama karoo & 5,243 & 4,971 & 569 \\
\hline & Savanna and thicket & 27,137 & 25,401 & 6,049 \\
\hline & Total & 96,393 & 90,592 & 19,801 \\
\hline \multirow[t]{6}{*}{ Grazing } & Fynbos & 1,194 & 992 & 348 \\
\hline & Grassland & 13,155 & 13,103 & 5,089 \\
\hline & Succulent Karoo & 1,233 & 1,222 & 243 \\
\hline & Nama karoo & 8,112 & 8,112 & 3,197 \\
\hline & Savanna and thicket & 10,030 & 9,959 & 3,778 \\
\hline & Total & 33,726 & 33,389 & 12,656 \\
\hline \multirow[t]{6}{*}{ Biodiversity } & Fynbos & 5,320 & 5,101 & 2,579 \\
\hline & Grassland & 2,745 & 2,706 & 1,071 \\
\hline & Succulent Karoo & 239 & 237 & 124 \\
\hline & Nama karoo & 1,063 & 1,051 & 608 \\
\hline & Savanna and thicket & 12,782 & 12,626 & 4,847 \\
\hline & Total & 22,151 & 21,723 & 9,232 \\
\hline All ecosystem services & & 152,271 & 145,705 & 41,690 \\
\hline
\end{tabular}

levels of infestation with invasive alien plants, and estimates of the value saved due to invasive alien plant control efforts in the past
Table 4 The relative importance $(\%)$ of four groups of invasive alien plants in five terrestrial biomes in South Africa. Figures are based on spatial distribution data from Le Maitre et al. (2000)

\begin{tabular}{lllcc}
\hline Biome & $\begin{array}{l}\text { Fire-adapted } \\
\text { trees }\end{array}$ & $\begin{array}{l}\text { Invasive Australian } \\
\text { trees }\end{array}$ & $\begin{array}{l}\text { Invasive } \\
\text { succulents }\end{array}$ & $\begin{array}{l}\text { Subtropical } \\
\text { shrubs }\end{array}$ \\
\hline Fynbos & 20.3 & 79.5 & 0.1 & 0 \\
Grassland & 0.8 & 77.6 & 2.6 & 18.9 \\
Succulent Karoo & 4.8 & 94.4 & 0.8 & 0 \\
Nama karoo & 0 & 95.6 & 4.4 & 0 \\
Savanna and thicket & 2.3 & 21.6 & 42.2 & 34.0 \\
\hline
\end{tabular}

grasslands, and ZAR 1.5 billion from the protection of biodiversity in the fynbos. The biological control of invasive succulents was also estimated to have protected services that deliver a value of ZAR 2.9 billion, mostly in the savanna and thicket biomes.

Contribution of biological control to protecting ecosystem services

Experts estimated that biological control had contributed $5 \%$ to the overall control of fire-adapted trees. In the case of Hakea shrubs, mechanical control had a large impact on reducing the extent of invasions, and biological control prevented re-colonisation (Esler et al. 2010). No biological control is currently available for Pinus trees, which re-invade cleared areas, and may even be occupying areas cleared of Hakea. There is, however, a time-lag between mechanical clearing and re-infestation during which an increase in ecosystem service delivery is realised, resulting in a small degree of protection for ecosystem services.

The biological control of invasive Australian trees is aimed at reducing seed output which will slow or 
Table 5 The value of annual flow of benefits (ZAR millions; ZAR = South African rands; 1 US\$ $=7.7$ rands in January 2010 ) attributable to the biological control of four groups of invasive alien plants in five biomes in South Africa

\begin{tabular}{|c|c|c|c|c|c|}
\hline \multirow[t]{2}{*}{ Ecosystem service } & \multirow[t]{2}{*}{ Biome } & \multicolumn{4}{|c|}{ Invasive alien plant group } \\
\hline & & $\begin{array}{l}\text { Fire-adapted } \\
\text { trees }\end{array}$ & $\begin{array}{l}\text { Invasive } \\
\text { Australian trees }\end{array}$ & $\begin{array}{l}\text { Invasive } \\
\text { succulents }\end{array}$ & $\begin{array}{l}\text { Subtropical } \\
\text { shrubs }\end{array}$ \\
\hline \multirow[t]{6}{*}{ Water } & Fynbos & 12.50 & 683.12 & 0 & 0 \\
\hline & Grassland & 4.89 & $2,602.65$ & 0 & 0 \\
\hline & Succulent Karoo & 0.10 & 9.79 & 0 & 0 \\
\hline & Nama karoo & 0 & 132.38 & 0 & 0 \\
\hline & Savanna and thicket & 6.82 & 395.93 & 0 & 0 \\
\hline & Total & 24.32 & $3,823.86$ & 0 & 0 \\
\hline \multirow[t]{6}{*}{ Grazing } & Fynbos & 3.54 & 193.57 & 0.33 & 0.01 \\
\hline & Grassland & 2.09 & $1,112.35$ & 99.59 & 48.16 \\
\hline & Succulent Karoo & 0.58 & 55.79 & 1.37 & 0 \\
\hline & Nama karoo & 0 & 743.19 & 104.72 & 0 \\
\hline & Savanna and thicket & 4.26 & 247.25 & $1,194.48$ & 64.23 \\
\hline & Total & 10.48 & $2,325.13$ & $1,400.49$ & 112.39 \\
\hline \multirow[t]{6}{*}{ Biodiversity } & Fynbos & 26.21 & $1,432.47$ & 2.47 & 0.01 \\
\hline & Grassland & 0.44 & 234.12 & 20.96 & 10.14 \\
\hline & Succulent Karoo & 0.30 & 28.62 & 0.70 & 0 \\
\hline & Nama karoo & 0 & 141.47 & 19.93 & 0 \\
\hline & Savanna and thicket & 5.47 & 317.52 & $1,532.68$ & 82.41 \\
\hline & Total & 32.42 & $2,153.92$ & $1,576.75$ & 92.56 \\
\hline Total & & 67.22 & $8,329.91$ & $2,977.23$ & 204.95 \\
\hline
\end{tabular}

stop further spread. Past control has relied to some degree on mechanical clearing, and this effort has varied between the biomes. The expert group therefore allocated separate percentages to biomes. They agreed on values of 70, 28, 24, 24 and $30 \%$ for the contribution of biological control to the protection of ecosystems services derived from the fynbos, grassland, succulent karoo, Nama karoo and savanna and thicket biomes, respectively.

Invasive succulents posed a significant threat to rangelands before biological control was introduced. For example, the area invaded by Opuntia aurantiaca could have been 15 times greater had it not been for biological control (Zimmermann et al. 2004), and Opuntia ficus-indica had invaded over 1 million hectares the early 20th century, but is now under sustained ( $>60$ years), satisfactory control (the cactus now infests $<10 \%$ of the area originally colonized (Annecke and Moran 1978; Moran and Zimmermann 1991). Also, among several other cactus species, Opuntia stricta var. stricta (Hoffmann et al. 1999) and Cereus jamacura (Klein 1999) were brought under substantial control after the introduction of biological control. The expert group agreed that biological control had contributed $75 \%$ to the overall control of this group.

Biological control within the subtropical shrub group has been less successful. Both Chromolaena odorata and Caesalpinia decapetala remain invasive despite the release of agents. The level of biological control against Lantana camara has been highly variable (depending on the agents(s) used, the area invaded, and the considerable varietal differences of L. camara itself, Baars and Neser 1999) but overall has been rated as substantial (Zimmermann et al. 2004), so that the need for additional control measures has been significantly reduced. However, because $C h$. odorata and $\mathrm{Ca}$. decapetala (and perhaps other invasive species) have the potential to replace Lantana, it was agreed that the proportion of benefit attributable to biological control should be estimated at only $5 \%$ for the group as a whole. 
Invasive succulents posed a significant threat to rangelands before biological control was introduced. For example, the area invaded by Opuntia aurantiaca could have been 15 times greater had it not been for biological control (Zimmermann et al. 2004). Also, Opuntia ficus-indica had invaded over 1 million hectares the early 20th century, but is now essentially under complete control (van Wilgen et al. 2004). Two other species (Opuntia stricta and Cereus jamacura) were brought under substantial control after the introduction of biological control. The expert group agreed that biological control had contributed $75 \%$ to the overall control of this group.

Cost:benefit estimation and sensitivity analyses

The estimated net present value of protected benefits attributable to biological control, using the above proportions, ranged from ZAR 840 million in the case of fire-adapted trees to ZAR 104 billion in the case of invasive Australian trees (Table 6). The benefit:cost ratios associated with the four groups were all positive, and ranged from 50:1 in the case of subtropical shrubs to $3,726: 1$ in the case of invasive Australian trees (Table 6).

Sensitivity analyses revealed that benefit:cost ratios would remain positive even if the estimates of the two key variables were substantially reduced (Fig. 2). For example, the estimate of the proportion of benefit attributable to biological control could be reduced by between 98 and $99 \%$ without the benefit:cost ratios becoming negative. If the approximation of the area that would have been invaded had there been no control in the past (the second key variable) was also reduced (by up to $75 \%$ ), benefit:cost ratios remained were positive and remained so even when the first key variable was reduced by between 85 and $99 \%$, depending on the group of weeds.

\section{Discussion}

Biome-scale impacts of invasive alien plants

Most previous studies of the economic value of weed biological control have focussed on a single invasive alien plant species, but in this paper we have studied groupings of invasive alien plant species. The main problem with single-species approaches is that they do not address the problem of substitution, where an alien species that is brought under control can, and often is, replaced by another alien species that can have similar impacts. Attempts to estimate the combined value of weed biological control by aggregating the benefits of single-species control programs can lead to doublecounting (e.g. Page and Lacey 2006), and this will compromise the integrity of the estimates. Our study has attempted to overcome this approach by grouping species that have similar impacts and can replace each other in the landscape. In our examples, a degree of success has been achieved with Hakea and Lantana shrubs in fynbos and savanna ecosystems, respectively. However, it is likely that Pinus species will replace Hakea species in fynbos, and Chromolaena odorata will replace Lantana camara in savannas. For this reason, the contribution of biological control to the protection of ecosystem services in these biomes

Table 6 Estimated net present values (ZAR millions; ZAR = South African rands; 1 US\$ = 7.7 rands in January 2010) of ecosystem service benefits attributable to biological control of four groups of invasive alien plants in five terrestrial biomes in South Africa

\begin{tabular}{|c|c|c|c|c|}
\hline Biome & $\begin{array}{l}\text { Fire-adapted } \\
\text { trees }\end{array}$ & $\begin{array}{l}\text { Invasive } \\
\text { Australian trees }\end{array}$ & $\begin{array}{l}\text { Invasive } \\
\text { succulents }\end{array}$ & $\begin{array}{l}\text { Subtropical } \\
\text { shrubs }\end{array}$ \\
\hline Fynbos & 528 & 28,863 & 35 & $<1$ \\
\hline Grassland & 93 & 49,363 & 1,506 & 729 \\
\hline Succulent Karoo & 12 & 1,177 & 26 & 0 \\
\hline Nama karoo & 0 & 12,713 & 1,558 & 0 \\
\hline Savanna and thicket & 207 & 12,005 & 34,089 & 1,833 \\
\hline Total & 840 & 104,122 & 37,215 & 2,562 \\
\hline Benefit:cost ratio & $81: 1$ & $3,726: 1$ & $2,731: 1$ & $50: 1$ \\
\hline
\end{tabular}

Benefit:cost ratios compare the net present value (at $8 \%$ discount rate) of benefits to the net present value of the costs of biological control 
Fig. 2 Break-even points of the proportion of control attributable to biological control (expressed as a \% of an expert estimate) for a range of gains in the value of ecosystems services due to overall control effort (gains are expressed as \% of the base estimate made in this study)
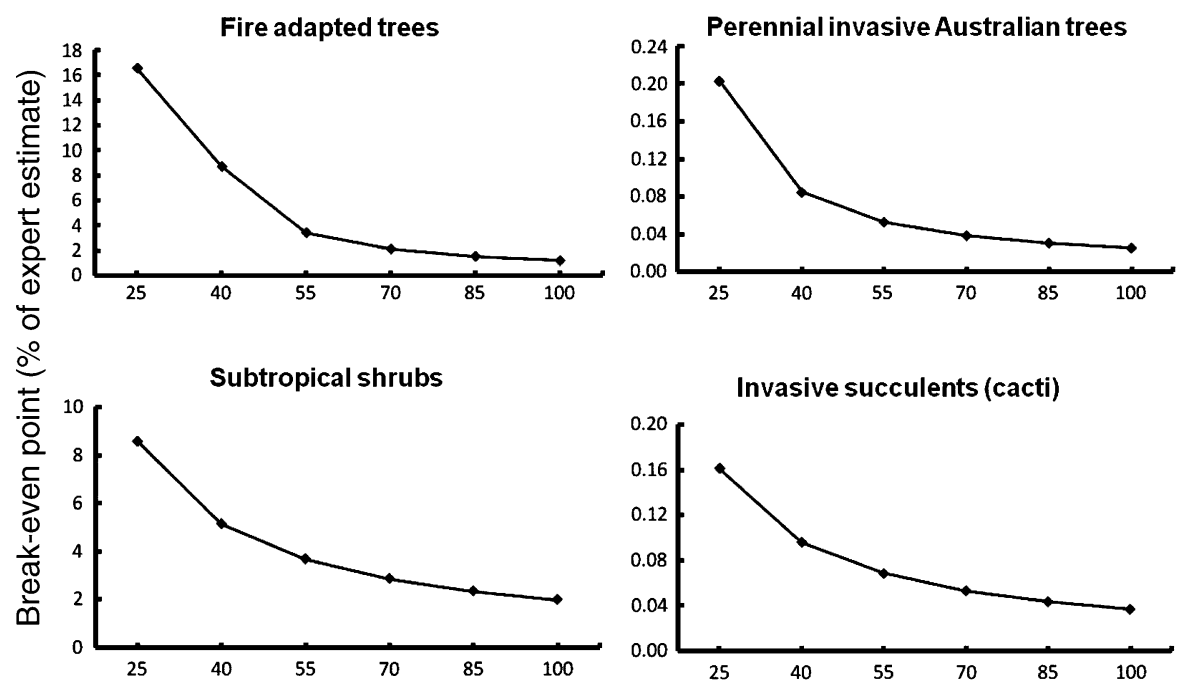

Gain due to control effort (\% of original estimate) was estimated as being very small (5\%). The full economic potential of biological control can only be realised if the entire suite of similar invasive alien plants is brought under control. This highlights the need for further research to identify additional biological control agents for the full suite of alien plants that invade particular ecosystems.

Estimating the value of biological control of invasive alien plants

The evaluation, in monetary terms, of the benefits of biological control is necessary, inter alia, for deciding on appropriate levels of funding to support research. The input data for this paper were derived from a study that quantified non-monetary benefits (van Wilgen et al. 2008). While that study was useful, the analysis presented here makes it possible to compare input costs with benefits, and can be used to demonstrate the return on investment offered by biological control. Our finding that biological control has brought about a substantial level of protection of ecosystem services is subject to potential errors in the estimation of two key variables, but the errors in our estimates would have to have been extremely large to reach a different conclusion. The approach proposed here has exposed the need for more accurate estimates of the effectiveness of different forms of control, as well as the plausible rates of spread. If these data become available, which is highly unlikely, they will considerably increase the levels of confidence in the results reported here. Otherwise, it would seem that these are the best estimates that are achievable at present, and that the main conclusions drawn from them are, in broad principle, if not in detail, unambiguous and compelling.

Risks and benefits associated with biological control of invasive alien plants

The use of biological control to address the problems of invasive species is controversial. On the one hand it can and has conferred significant benefits, but on the other it is seen by many as too risky to consider as a serious part of integrated control measures. Published opinions on these matters often appear in the scientific literature (for example Moran et al. 2005; Simberloff and Stiling 1996; Louda and Stilling 2003) further promoting the perception of large risks. At best, this leads to excessively stringent requirements for the introduction of biocontrol agents, and at worst to the total avoidance of the use of biological control as an option (McFadyen 2004; Sheppard et al. 2006).

The arguments for the use of biological control include that it is cost effective and very safe compared with the expense and risks associated with herbicide development and deployment; that biological control can be successfully integrated with other management practices; and, most compelling of all, 
that biological control is self-sustaining (Moran et al. 2005). The arguments against biological control maintain that the outcomes of an introduction cannot be predicted precisely enough a priori to know with any certainty that the benefits will outweigh the environmental costs. Proponents of this view often point to examples of unintended consequences, such as impacts on non-target species, and the disruption of food webs, in support of their views.

In an increasingly risk-averse world, the problem that arises is that, more and more, a precautionary approach is taken, and biological control agents are not released, or in some cases not even considered as a possible option for control (see McFadyen 2004; Sheppard et al. 2006). However, avoiding biological control and relying on mechanical and chemical methods alone, is both expensive and unsustainable.

\section{Implications for management}

The work reported here suggests that the returns on investment from biological control research are substantial. Benefit-cost ratios of the value of ecosystem services protected to the costs of research are very high, and they remain high when subjected to sensitivity analysis. A number of additional factors need to be considered in this regard. The first relates to the risks associated with biological control. In this regard, it is important to differentiate between weed biological control (the use of carefully selected and tested plantfeeding insects, mites, and pathogens against plants) and other forms that use, for example, generalist vertebrate predators for pest control (Moran et al. 2005). The former is relatively safe, while the latter often is not. By combining these two forms of management under the umbrella phrase of "biological control", impressions can be created (especially amongst non-specialist managers) that the risks of introducing biological control agents are unacceptably high. Many such judgements of risk are also made without considering the risks associated with not introducing biological control (for example, the risks of losing ecosystem services, as reported here). The second factor relates to the sustainability of control efforts. Invasive alien plant control using manual or chemical methods is expensive, also carries risks, and most importantly is not sustainable. The target species are almost never eradicated, and as soon as budgets are cut, the gains made in clearing can rapidly be lost through re-invasion of cleared sites. The fact that biological control, once implemented, is sustainable represents a very strong argument for its use. However, biological control often receives a relatively small proportion of funds allocated to control. For example, South Africa's Working for Water programme (van Wilgen et al. 1998) currently spends 600 million rands ( 1 US $\$=7.7$ rands in January 2010) annually on invasive alien plant control, of which only $1.6 \%$ goes to biological control. The maintenance of the capacity to conduct this research (in the form of trained scientists, quarantine facilities and the like) is also an important consideration here, for if it is allowed to decline, it would be very difficult to recreate. It is our opinion, therefore, that biological control should receive greater prominence in control efforts that it currently does.

Acknowledgments We thank Cliff Moran and John Hoffmann for suggesting that individual weed species be combined into functional groupings for these analyses, and we thank the numerous experts who assisted with the estimations of the relative contribution of biological control. The Plant Protection Research Institute, the University of Cape Town and Rhodes University allowed us access to records that led to the costing of research. This work was funded by the South African Working for Water programme of the Department of Water and Environmental Affairs.

\section{References}

Annecke DP, Moran VC (1978) Critical reviews of biological pest control in South Africa. 2. The prickly pear, Opuntia ficus-indica (L.) Miller. Journal of the Entomological Society of southern Africa 41:161-188

Baars J-R, Neser S (1999) Past and present intitatives on the biological control of Lantana camara (Verbenaceae) in South Africa. African Entomology Memoir 1:21-33

Biggs R, Reyers B, Scholes RJ (2006) A biodiversity intactness score for South Africa. S Afr J Sci 102:277-283

Buhlea ER, Margolis M, Ruesink J (2005) Bang for buck: costeffective control of invasive species with different life histories. Ecological Economics 52:355-366

Culliney TW (2005) Benefits of classical biological control for managing invasive plants. Crit Rev Plant Sci 24:131-150

De Lange WJ, Kleynhans TE (2008) Long-term water resource management in semi-arid areas: a South African case study. International Journal of Sustainable Development and Planning 3:1-19

De Wit MP, Crookes DJ, van Wilgen BW (2001) Conflicts of interest in environmental management: estimating the costs and benefits of a tree invasion. Biol Invasions 3:167-178

Esler KJ, van Wilgen BW, Te Roller KS, Wood AR, van der Merwe JH (2010) A landscape-scale assessment of the 
long-term integrated control of an invasive shrub in South Africa. Biol Invasions 12:211-218

Federal Interagency Committee for Management of Noxious and Exotic Weeds (1998) Pulling together: a national strategy for management of invasive plants, 2nd edn. United States Government Printing Office, Washington, DC

Hassan RM (2003) Measuring asset values and flow benefits of non-traded products and ecosystem services of forest and woodland resources in South Africa. Environ Dev Sustain 5:403-418

Higgins SI, Turpie J, Costanza R, Cowling RM, Le Maitre DC, Marais C, Midgley GF (1997) An ecological economic simulation model of mountain fynbos ecosystems: Dynamics, valuation and management. Ecological Economics 22:155-169

Hoffmann JH, Moran VC, Zimmermann HG (1999) Integrated management of Opuntia stricta (Haworth) Haworth (Cactaceae) in South Africa: an enhanced role for two, renowned, insect agents. African Entomology Memoir $1: 15-20$

Jarvis PJ, Fowler SV, Paynter Q, Syrett P (2006) Predicting the economic benefits and costs of introducing new biological control agents for Scotch broom Cytisus scoparius into New Zealand. Biol Control 39:135-146

Klein H (1999) Biological control of three cactaceous weeds, Pereskia aculeata Miller Harrisia martini (Labouret) Britton and Cereus jamacara de Condolle in South Africa. African Entomology Memoir 1:3-14

Law MC (2007) Willingness to pay for the control of water hyacinth in an urban environment of South Africa. Thesis, Rhodes University, Grahamstown

Le Maitre DC, Versfeld DB, Chapman RA (2000) The impact of invading alien plants on surface water resources in South Africa: a preliminary assessment. Water SA 26:397-408

Louda SM, Stilling P (2003) The double-edged sword of biological control in conservation and restoration. Conserv Biol 18:50-53

McConnachie AJ, De Wit MP, Hill MP, Byrne MJ (2003) Economic evaluation of the successful biological control of Azolla filiculoides in South Africa. Biol Control 28: 25-32

McFadyen RE (2004) Biological control: managing risks or strangling progress? In: Sindel BM, Johnson SB (eds) Proceedings of the 14th Australian Weeds Conference of the Weed Society of New South Wales, Sydney, pp 78-81

McNeeley JA, Mooney HA, Neville LE, Schei P, Waage JK (2001) A global strategy on invasive alien species. IUCN, Gland

Moran VC, Zimmermann HG (1991) Biological control of jointed cactus, Opuntia aurantiaca (Cactaceae), in South Africa. Agric Ecosyst Environ 37:5-27

Moran VC, Hoffmann JH, Zimmermann HG (2005) Biological control of invasive alien plants in South Africa: necessity, circumspection, and success. Frontiers in Ecology and the Environment 3:77-83

Page AR, Lacey KL (2006) Economic impact assessment of Australian weed biological control. Technical series report prepared by the AEC group for the CRC for
Australian Weed Management, Waite Campus, University of Adelaide

Perrings C, Mooney H, Williamson M (2010) Bio-invasions and globalization: ecology, economics, management, and policy. Oxford University Press, Oxford

Pimentel D (2002) Biological invasions: Economic and environmental costs of alien plant, animal and microbe species. CRC Press, Boca Raton

Pimentel D, Zuniga R, Morrison D (2005) Update on the environmental and economic costs associated with alieninvasive species in the United States. Ecological Economics 52:273-288

Pringle KL, Heunis JM (2006) Biological control of mites in apple orchards in the Elgin area of South Afrca using a predatory mite: a cost-benefit anlysis. African Entomology 14:113-121

Richardson DM, Macdonald IAW, Hoffmann JH, Henderson L (1997) Alien plant invasions. In: Cowling RM, Richardson DM, Pierce SM (eds) Vegetation of southern Africa. Cambridge University Press, Cambridge, pp 535-570

Rouget M, Richardson DM, Nel JL, Le Maitre DC, Egoh B, Mgidi T (2004) Mapping the potential ranges of major plant invaders in South Africa, Lesotho and Swaziland using climatic suitability. Divers Distrib 10:475-484

Scholes RJ, Biggs R (2005) A biodiversity intactness index. Nature 434:45-49

Shackleton CM, Shackleton SE (2004) The importance of nontimber forest products in rural livelihood security and as safety nets: a review of evidence from South Africa. S Afr J Sci 100:658-664

Sheppard AW, Shaw RH, Sforza R (2006) Top 20 environmental weeds for classical biological control in Europe: a review of opportunities, regulations and other barriers to adoption. Weed Res 46:93-117

Simberloff D, Stiling P (1996) Risks of species introduced for biological control. Biol Conserv 78:185-192

Statistics South Africa (2004) Census of commercial agriculture 2002 (Summary). Statistics South Africa, Pretoria; http://www.statssa.gov.za/publications/Report-11-02-01/ CorrectedReport-11-02-01.pdf

Turpie JK (2003) The existence value of biodiversity in South Africa: how interest, experience, knowledge, income and perceived level of threat influence local willingness to pay. Ecological Economics 46:199-216

Turpie J (2004) The role of resource economics in the control of invasive alien plants in South Africa. S Afr J Sci 100:87-93

Turpie J, Heydenrych BJ, Lamberth S (2003) Economic value of terrestrial and marine biodiversity in the Cape Floristic Region: implications for defining effective and socially optimal conservation strategies. Biol Conserv 112: 233-251

van Wilgen BW, Le Maitre DC, Cowling RM (1998) Ecosystem services, efficiency, sustainability and equity: South Africa's working for water programme. Trends Ecol Evol 13:378

van Wilgen BW, van der Heyden F, Zimmermann HG, Magadlela D, Willems T (2000) Big returns from small organisms: developing a strategy for the biological control of invasive alien plants in South Africa. S Afr J Sci 96:148-152 
van Wilgen BW, Richardson DM, Le Maitre DC, Marais C, Magadlela D (2001) The economic consequences of alien plant invasions: examples of impacts and approaches to sustainable management in South Africa. Environ Dev Sustain 3:145-168

van Wilgen BW, De Wit MP, Anderson HJ, Le Maitre DC, Kotze IM, Ndala S, Brown B, Rapholo MB (2004) Costs and benefits of biological control of invasive alien plants: case studies from South Africa. S Afr J Sci 100:113-122 van Wilgen BW, Reyers B, Le Maitre DC, Richardson DM, Schonegevel L (2008) A biome-scale assessment of the impact of invasive alien plants on ecosystem services in South Africa. Journal of Environmental Management 89:336-349

van Wyk E, van Wilgen BW (2002) The cost of water hyacinth control in South Africa: a case study of three options. African Journal of Aquatic Science 27:141-149

Zimmermann HG, Moran VC, Hoffman JH (2004) Biological control in the management of invasive alien plants in South Africa, and the role of the Working for Water programme. S Afr J Sci 100:34-40 